\title{
COLLABORATIVE DESTINATION MANAGEMENT OF V4 COUNTRIES AND GERMANY DURING THE COVID-19 PANDEMIC
}

\author{
Gabriela Antošová1* , Clara Hausmann², Verena Pfeifer ${ }^{3}$ \\ ${ }^{1}$ Czech Technical University, Masaryk Institute of Advanced Studies, Czech Republic \\ ${ }^{2,3}$ Catholic University of Eichstätt-Ingolstadt, Germany
}

\begin{abstract}
Tourism destinations need to develop a coordinated approach to the development of new tourism options. One possibility is to strengthen domestic tourism in the own country and to support local hotels and restaurants. However, rebuilding the destination requires a coordinated approach; for instance, collaborations with cross-border regions. Collaborative destination management is an approach to work with partner countries to jointly address the challenges of pandemics by establishing different types of tourism. Recommendations for action are identified from the PESTLE and SWOT analysis to ensure successful collaborative destination management of V4 countries and Germany during the Covid-19 pandemic. These analyses were performed because of brainstorming and the Delphi method with 4 experts from several fields of this study. Therefore, a strategy based on the TOWS Matrix reflects what a new collaborative destination management approach could look like during the current crisis for the Euroregions.
\end{abstract}

Keywords: Visegrad Group countries (V4), Coronavirus, Germany, collaborative destination management

\section{Introduction}

Due to the Covid-19 pandemic, there are entry controls at the national borders and measures to restrict free movement in the European Union (EU) during the pandemic. As a result, tourism in the EU is also restricted and restaurants, hotels or bars have closed. The restrictions caused a $75 \%$ loss of revenue in the entire tourism sector across the EU. It is also predicted that the overall recovery process will take between two and four years (Niestadt, 2020).Tourism destinations need to develop a coordinated approach to the development of new tourism options. One possibility is to strengthen domestic tourism in the own country and to support local hotels and restaurants. However, to rebuild the destination requires a coordinated approach; for instance, collaborations with cross-border regions. Collaborative destination management is an approach to work with partner countries to jointly address the challenges of pandemics by establishing different types of tourism. Due to the closure of tourist attractions, for instance UNESCO Heritage sites such as national parks, monuments, or even city centers, virtual and digital tourism can be new possible developments (Iguman, 2020).

This leads to the following research question: Which recommendations for action can be identified from the PESTLE and SWOT analysis to ensure successful collaborative destination management of V4 countries and Germany during the Covid-19 pandemic? Therefore, a strategy based on the TOWS Matrix reflects what a new collaborative destination management approach could look like during the current crisis for the Euroregions. To begin with, an overview of the Euroregions and their importance in the border regions of Germany and the Czech Republic will be given. Afterwards, the PESTLE analysis with its corresponding steps political, economic, social, technological, legal, and environmental and the steps of the SWOT analysis strengths, weaknesses, opportunities, and threats are applied. Before the strategic planning process, these analyses were performed as a result of brainstorming and the Delphi method with German (2) and (zech (2) experts from the field of this study. The first mentioned question was 4 times rounded in the brainstormed activity ( $1^{\text {st }}$ round in February, $2^{\text {nd }}$ round in March, $3^{\text {rd }}$ April, and $4^{\text {th }}$ round in May 2021) and the Delphi method process for several discussions and mid-mapping process. Finally, the results were settled to the matrix.

\section{Overview of the Euroregions in the Czech Republic and Germany}

The Euroregions are, same as the cross-border cooperation, developed by modern policy of economic and social cohesion. Border regions between the Czech Republic and Germany receive financial support from the European Union for cross-border projects with the so-called Interreg (Interreg, 2020). $A$ border region is defined as an area that is in close proximity to the border and is affected by this proximity. Moreover, the regions at the borders are influenced by the "border effect" which is dependent by the openness and compatibility of neighboring regions (Abrhám, 2017). Cross-border cooperation is taking place in the border regions to achieve more modern policies and both economic and social cohesion. It is not only a cooperation between the citizens, but also institutions, municipalities, cities and regions, which have all different perspectives of the border areas (Abrhám, 2017).

The regions use the Euroregion membership to finance their economic activities for instance in the traffic, economy and tourism sector, environment and climate protection, energy, risk management, culture education and knowledge and the support of cross-border cooperation (Euroregion NeisseNisa-Nysa 2, 2014).

The border regions between Germany, the Czech Republic, Austria, and Poland are presented below. The projects of the regions are individually adapted to needs and requirements of destinations.

$\square$ Neisse/Nisa/Nysa (DE, CZ, PL; since 1991).

Library "Building of Reconciliation" for information and educational opportunities.

Reforestation measures.

Opening of more than 10 border crossings for hikers and cyclists. 
$\square$ Elbe/Labe (DE, CZ; since 1992).

Binational grammar school for German and Czech pupils.

Culture pass for reduced admission prices to cultural institutions.

$\square$ Erz Mountains-Krušnohoří (DE, CZ; since 1992).

Joint counselling centre and events, for instance the theatre festival.

Quarterly joint magazine "Infopress".

$\square$ Egrensis (DE, CZ; since 1993).

Host school year at German or Czech grammar schools.

Long-distance cycle route "Euroregio-Ergensis-Südtour" with a length of $525 \mathrm{~km}$.

$\square$ Bavarian Forest - Šumava - Mühlviertel (DE, CZ, AT; since 1994). Improving cross-border local transport.

Euroregion host school year.

Public transport structure and potential analysis for the improvement of cross-border local transport (Auswärtiges Amt, 2021).

The next part is presented as a strategic plan of the selected collaborative destination:

\section{Strategic objectives}

\section{Mission}

All regions have planned different goals and actions that they would like to implement. In the tourism sector, a joint concept is being developed by the Saxon Switzerland Tourist Board and the Bohemian Switzerland Nonprofit Association to present the Elbe Sandstone Mountains as a cross-border destination for tourists ("Eine europäische Destination":..., 2021). In the tourism industry, several stakeholders are involved in interactively addressing a problem or a set of issues. Therefore, the inter-destination collaboration is defined as "the means by which destinations can work in partnership with other destinations in improving inter-regional, inter-state and interdestination products" (Naipaul et al., 2009).

According to Naipaul et al., 2009 the collaborative destination management is a possible management approach for the regions to connect destinations more strongly and make the cooperation even more transparent to create a fair environment and thus build trust, as this is a decisive factor for the success or failure of a collaborative project. Collaborative destination management is again distinguished between intra- and inter-destination collaboration. However, there is often a lot of competition between DMOs. These competitions lead to a region weakening the efficiency and effectiveness of regional tourism development. Increased competitive pressure has led to collaboration between tourist destinations (Naipaul et al., 2009). Bramwell and Lane (2000) argue that the combination of knowledge, expertise, and capital leads to a collaborative strategy that leads to new opportunities, innovative solutions, and a higher level of effectiveness that would not have been achieved by the partners alone.

The motivational reasons for a collaborative partnership can be rationalized to three concrete approaches: Strategic, transaction costs, and the associated learning effects (Naipaul et al., 2009).

$\square$ Strategic: to enhance a business's competitive advantage through market power and efficiency by sharing risks and uncertainty.

$\square$ Transaction costs: to reduce production and transaction costs and to exploit economies of scale and scope.

$\square$ Learning: to learn skills and capabilities from partners and access new technology and know-how.

\section{Goals}

The border regions have a less developed infrastructure, fewer job opportunities, and a lower economic level. The Euroregion was developed to provide not only a national solution to these problems, but to develop cooperation between the border areas. Therefore, the Euroregions are defined as "associations of local entities and institutions on both sides of the border with a specialized personnel structure" (Abrhám, 2017).

With the implementation of a collaborative destination approach, the border regions have facilitating factors in forming partnerships and inhibiting factors to partnership formation (Table 1).

Table 1 Key Areas in Collaborative Regional Destination Marketing

\begin{tabular}{|c|c|}
\hline Facilitators & Inhibitors \\
\hline $\begin{array}{l}\text { Efficient and effective exchange of } \\
\text { resources }\end{array}$ & additional financial and time costs \\
\hline $\begin{array}{l}\text { Generation of increased visitor flow } \\
\text { and positive economic empact }\end{array}$ & no recognition of collaboration value and benefits \\
\hline Broadening of destination domain & reduction of direct control \\
\hline Frequent communication & political/economic/administrative challenges \\
\hline Perception of equal benefit and trust & $\begin{array}{l}\text { mistrust and suspicion (leakage of skills, } \\
\text { knowledge, etc.) }\end{array}$ \\
\hline
\end{tabular}

The Covid-19 pandemic is a major obstacle and challenge for the crossborder Euroregions of the V4 countries because with closed borders, there is no cross-border contact between the countries.

Tourism destinations that rely on tourists from the neighboring countries there was recorded a heavy impact of the pandemic (Peyrony, 2020). Cross-border organizations such as the Euroregions need to keep the cooperation alive during the Covid-19 crisis because "cross-border and transnational cooperation are not only wanted by Europe's citizens but they are also essential for the livelihoods of many of them" (European Week of Regions and (ities, 2020). The challenge is to continue organizing events to keep up the morale of the local population and commit to cross-border cooperation (Peyrony, 2020).

\section{Market analysis}

"Every enterprise operates in the context of a dynamic external environment" (Inagson and Jonasson, 2019). Thus, as a first step towards finding strategic recommendations for action for the Euroregions, the PESTLE analysis was performed to provide a holistic view of the macrolevel environment and the various external factors influencing the Euroregions' current operations. The PESTLE analysis is an extension of the well-established PEST framework. According to Inagson and Jonasson (2019), letters in the acronym can be added or neglected depending on the relevance for the examined organisation. The complementing of a legal and environmental angle to the analysis of the regular macro-environmental factors (political, economic, social, and technological) ensures for the complex market environment within the tourism industry to be properly replicated in the analysis. The challenges inflicted onto the industry during the past years in the context of pandemic and climate crisis management emphasise the relevance of the legal and environmental factors for the tourism business.

$\square$ Political factors: What is the political situation in the collaborating countries and how can it affect the industry?

One of the most evident political factors affecting tourism is the closure of national borders and the restriction of the freedom of travel even within 
the European Union. In addition to this obstacle, policies to mitigate the crisis primarily focus on preserving other economic sectors while tourism is neglected. Regardless of the pandemic, another important political factor for the Euroregions is the support from political associations such as the Visegrad Group or the European Union. An example of this ongoing political patronage for cross-border cooperation is how the current Polish Presidency of the Visegrad Group commits to carrying out "actions to increase cross-border tourism between neighboring regions, for example by developing common cross-border tourism products" (Visegrad Group, 2020).

\section{$\square$ Economic factors: What are the prevalent economic factors?}

Evidently, tourism in the Euroregions is influenced by several economic factors. Two or even three different currencies (Euro, (zech Crown, Polish Zloty) are in use in all the interstate Euroregions studied, a fact which may complicate cross-border tourism and affects the customer experience. On a more positive note, the rising disposable income for large sections of the global population increases the tourism consumption expenditure and number of potential tourists.

$\square$ Social factors: How much importance does culture have in the market and what are its determinants?

Culture and related social factors play an important role in the tourism industry. For example, the increasing societal diversity and, thus, the Euroregions' expansion of target groups are important market factors. Moreover, the growing popularity of regional tourism and ecotourism boosts the Euroregions' business potential. However, we also identified negative social effects on the Euroregions' market due to the Covid-19 pandemic. On the one hand, the fear of infection reduced people's desire to travel (OECD, 2020). On the other hand, due to the narrowed selection of possible destinations while European borders were closed, unintentional mass tourism occurred in some hotspots which tourists classified as safe.

$\square$ Technological factors: What technological innovations are likely to pop up and affect the market structure?

The biggest technological factor influencing Euroregions' business operations are the regionally slow progress of digitization and the resulting discrepancies in digital development. Naturally, the Euroregions are located in peripheral border regions. Peripheral regions often lag behind regions closer to important metropolises in terms of technological development such as broadband expansion or cellular networks.

$\square$ Legal factors: Are there any current legislations that regulate the industry or can there be any change in the legislations for the industry?

Legal factors include the legal and bureaucratic requirements and legal framework that must be adhered to in order to fulfil the financing conditions of e.g., the INTERREG funding. Regarding the Covid-19 pandemic, legal regulations for the purpose of pandemic mitigation, like exit barriers or bans on trips, have severely impacted cross-border tourism.

$\square$ Environmental factors: What are the environmental concerns for the industry?

Lastly, an important environmental factor influencing the Euroregions' operations is - as already mentioned in the section on technological factors the obstacles caused by the peripheral location, resulting in regionally poor infrastructure and lacking traffic links within the Euroregions. A positive environmental factor for tourism is the season creep (longer warm seasons, shorter cold seasons) and the resulting reorientation towards a year-round tourism offer.

\section{Situation analysis}

Building on the findings of the macro-level analysis, a SWOT analysis was performed (see Table 1).

A "SWOT analysis provides a structured way of compiling information, extracting the essentials and presenting these results in a readily understood matrix format" (Inagson and Jonasson, 2019). While the strengths and weaknesses relate to internal factors of the company, the detected opportunities and threats result from external factors and were deducted from the previous PESTLE analysis. The complete SWOT analysis is depicted in Table 2. In the following, some of these aspects will now be further elaborated and commented on.

\section{EUROREGION}

Figure 1 Logo of Euroregion Neisse-Nisa-Nysa

A strength of the collaborative destination management in the Euroregion is the implementation of joint marketing operations. One example is the introduction of a common, trilingual logo in the Euroregion Neisse-NisaNysa (see Figure 1) which strengthens the expression of cohesion within the region. A further strength is the prevalence of soft tourism and adventure tourism offers such as biking or hiking in the Euroregions. As these offered activities are in accordance with the current change of tourist demand and consumer behaviour, this fact represents a great potential for the tourism success of the regions (Center for Responsible Travel, 2018).

Nevertheless, several weaknesses of the Euroregions could be carved out. One weakness is the lack of funds and, therefore, little investment in digitization and innovation (Euroregion Neisse-Nisa-Nysa 1). The regions' location in the peripheral, less developed parts of the countries inhibits the development of virtual tourism or innovative visitor guidance concepts. Moreover, due to the special cross-border situation of the regions, the service for tourists must be provided in multiple languages. Since a core concern of the Euroregions is to attract visitors from the foreign parts of the region, services such as navigation labelling or assistance in visitor orientation must also be offered in the other regional languages. The Euroregion Neisse-Nisa-Nysa, for instance, has stated that there is still room for improvement in these issues (Euroregion Neisse-Nisa-Nysa 1). A further obstacle is posed by political, economic, and administrative challenges. For instance, the collaborating countries tend to have different perceptions of tourism development or are differently advanced in the field of destination management which complicates the cooperation of the actors (Euroregion Neisse-Nisa-Nysa 2, 2014).

Several opportunities for inter-destination cooperation in the examined Euroregions could be identified from external factors in the PESTLE analysis. One example is the political support of cross-border cooperation and the promotion of regional development by associations such as the Visegrad Group (Visegrad Group, 2020) and ongoing funding programs such as the EU INTERREG funding. Another opportunity is the decline of seasonality in tourism and, therefore, the reorientation towards year-round tourism offers which enables a more permanent flow of visitors to the Euroregions. The growing appreciation of and awareness for regionality across all age groups 
Table 2 SWOT analysis of the assessed Euroregions

\begin{tabular}{|l}
\hline Facilitators \\
\hline joint marketing and high quality of marketing material: image brochures, multilingual information boards, introduction \\
of a common logo (e. g.: Euroregion Neisse-Nisa-Nysa) \\
\hline quality manager \\
\hline soft tourism and adventure tourism \\
\hline interactive virtual maps for customers \\
\hline inter-destination networking of tourist information \\
\hline Weaknesses \\
\hline additional financial and time costs \\
\hline reduction of direct control \\
\hline lack of funds causes regionally little investment in digitization and innovation \\
\hline need for action in multilingual navigation labelling and visitor orientation \\
\hline bureaucratic requirements \\
\hline political, economic, and administrative challenges \\
\hline Opportunities \\
\hline rising disposable income increases travel possibilities \\
\hline expansion of the national park railroad as a connecting tourist project \\
\hline higher variety of target groups \\
\hline alternative form of tourism (eco-tourism) \\
\hline promotion of regional development through associations and funding programs \\
\hline support from the EU (e. g.: INTERREG funding) \\
\hline creation of joint cross-border tourism offers \\
\hline reorientation towards year-round tourism offers \\
\hline bureaucracy \\
\hline lack of a common currency impedes mobility, trade, and collaboration \\
\hline
\end{tabular}

Source: own elaborations based on Abrhám 2017; European Week of Cities and Regions, 2020; Euroregion Neisse-Nisa-Nysa 2, 2014; OECD, 2020; Visegrad Group, 2020

Table 3 TOWS Matrix

\begin{tabular}{|c|c|c|}
\hline \multicolumn{2}{|l|}{ Weaknesses } & Strengths \\
\hline Threats & $\begin{array}{l}\text { WT } \\
\text { acquire funding to improve expansion of } \\
\text { infrastructure and digitization } \\
\text { improve interregional cooperation to ensure } \\
\text { greater resilience }\end{array}$ & $\begin{array}{l}\text { ST } \\
\text { recovery through sharing economy in tourist } \\
\text { destination } \\
\text { elaborating thorough hygiene concepts }\end{array}$ \\
\hline Opportunities & $\begin{array}{l}\text { W0 } \\
\text { regional tourism } \\
\text { digital and virtual tourism } \\
\text { visitor guidance measures }\end{array}$ & $\begin{array}{l}\text { SO } \\
\text { increase customer portfolio through networking } \\
\text { increase sustainable tourism offer } \\
\text { expansion of cross-border products }\end{array}$ \\
\hline
\end{tabular}

Source: Own elaboration and as a result, the higher variety of potential target groups for the Euroregions, represent another important opportunity.

However, several external threats for the Euroregions need to be taken into consideration when formulating recommendations for strategic actions. On the one hand, general threats like the high bureaucratic effort of collaborative destination management, the lack in digitization and reliable infrastructure or the challenges the tourism industry is facing because of climate change need to be a special focus. On the other hand, there are current Covid-19 related threats for the Euroregions, such as the closure of national borders and the restriction of the freedom of movement within the European Union or the omnipresent fear of infection.

\section{Implementation plan}

With the aim of formulating a strategic action plan for improved collaboration within the Euroregions, a TOWS Matrix (see Table 2) was developed based on the previous SWOT analysis. This matrix is a "conceptual framework for a systematic analysis that facilitates matching the external threats and opportunities with the internal weaknesses and strengths of the organization" (Weihrich, 1982). Firstly, an analysis of the external environment is required. The focus is on the listed threats $(T)$ and the opportunities $(0)$ and the internal environment based on the strengths $(S)$ and weaknesses (W) of the Euroregions which are already identified in the SWOT analysis. The TOWS matrix enables the organization to formulate specific strategies, tactics, and actions to transform current conditions for future research on the combination of external and internal factors (Ravanavar and (harantimath, 2012). It is also used to identify internal factors and strategies based on these variables (Dandage et al., 2019).

The following strategic groups are identified in the TOWS matrix:

$\square$ Weaknesses-threats (WT): the strategies are to be formulated that the weaknesses of the project organization will be minimized, and the threats will be avoided.

$\square$ Weakness-opportunity (W0): based on the opportunities available to the project organization, the strategies are to be formulated to overcome the weaknesses of project organization.

$\square$ Strength-threats (ST): based on the strengths of project organization, the strategies are to be formulated to overcome the threats to the project organization. 
$\square$ Strength-0pportunity (SO) strategies are to be formulated to make the best use of opportunities available to the project organization (Dandage et al., 2019).

Based on the PESTLE and SWOT analysis there were developed some strategies with the TOWS Matrix to adapt and improve the approaches of the Euroregions (Table 3).

The strategy options derived from the SWOT analysis match the external opportunities and threats with the internal strengths and weaknesses and, respectively, aim to maximise the positive or minimise their negative effects:

\section{$\square$ Weaknesses and threats (WT)}

The factors in the external environment, particularly the infrastructure as for instance the train and bus connections in the cross-border regions, the little organized bureaucracy, climate change and the low digitalization in the tourism sector are serious threats to the countries of the Euroregions. With the weaknesses such as the regionally little investment in digitization and innovation like inhibitors for virtual tourism and visitor guidance concepts it is necessary to set up a new concept for the cross-border regions. The Euroregions should try to acquire more funding from various programs to improve the expansion of infrastructure and digitization. Intact roads, good transport connections and reliable public transport are vital for the touristic success of the regions. Moreover, interregional cooperation needs to be improved, for example, through the establishment of appropriate structures or the intensification of joint destination management (Euroregion NeisseNisa-Nysa 2, 2014). The improved cooperation will ensure greater resilience in future crises.

\section{$\square$ Weaknesses and opportunities (W0)}

Without investing in good digitization, the Euroregions' destinations are not able to promote their tourist regions for foreigners or show them some tourist spots while national borders are closed. Therefore, the Euroregions should use the political commitment to the promotion of interregional cooperation and invest in the expansion of digital and virtual tourism offers. This investment would minimise the backlog in digitalisation while appealing to younger target groups. Consequently, the Euroregions can take advantage of good technological offers and expand their digital and virtual tourism for foreigners by initiating virtual tours of castles, natural highlights, or museums etc. Innovative and comprehensible visitor guidance concepts should be elaborated and enforced, whereby social and digital media channels could also be used. Visitor guidance measures are indispensable for distributing the crowds of tourists when borders re-open. The crisis is an opportunity to rethink tourism for the future and carry out new tasks, for instance industry workshops or e-learning platforms for employees (OECD, 2020).

\section{$\square$ Strength and threats (ST)}

To cope with the threats in the external environment, the Euroregions may use their internal strengths to minimise possible threats. Specifically, sharing economy can alleviate the problems caused by the pandemic, accelerate the post-crisis recovery, and enable the use of untapped resources and potentials. Similarly, the cooperation with private travel agencies in and outside the V4 regions increases the financial possibilities of the Euroregions to continue activities carried out in previous years on selected remote markets (Visegrad Group, 2020). Additionally, the joint elaboration of thorough hygiene concepts to minimise the risk of infection facilitates cross-border travel and would enable an imminent restart of touristic activities once the travel restrictions are loosened.

\section{$\square$ Strength and opportunities (SO)}

Lastly, the Euroregions need to use their strengths to take advantage of their opportunities. For instance, the already established cross-border contact and relations with other Euroregions could be used to increase the customer portfolio through networking. Cross-border products can be used to expand the marketing of the V4 destination and carry out actions to increase crossborder tourism between neighbouring regions (Euroregion Neisse-NisaNysa 2, 2014; Visegrad Group, 2020). An important contribution to the good reputation of the Euroregions is their focus on sustainable tourism. Hence, the sustainable tourism offer should be expanded even further to continue exploiting the advantage of the current tourist demand. Interactive maps, which are available to customers on the Internet, can on the one hand provide orientation for tourists on signposted routes and on the other hand contribute to nature conservation. To equalise tourist flows in popular tourist regions, it is also necessary to develop a concept for visitor guidance measures. On the one hand, these measures should protect the monuments and nature and on the other hand, it is important to consider the needs of the local population and create a «green belt» in certain regions.

\section{Conclusions}

The Euroregions which were examined in this paper are very engaged in maintaining and promoting partnerships between cross-border destinations in the Czech Republic, Poland, and Germany. The PESTLE Analysis provided an overview of the positive and negative effects of some political, economic, sociological, technological, legal, and environmental factors which influence the Euroregions' business ecosystem. This market analysis was a necessary step to understand the Euroregions' business operations and to identify the respective strengths, weaknesses, opportunities, and threats. We propose strategic recommendations for action. Even though national borders were closed because of the Covid-19 pandemic and - for several months in 2020 and 2021 - no foreign tourists were allowed to travel to cross-border destinations, we formulated several recommendations for cross-border destination collaboration.

One recommendation is the sharing tourism recovery plans to support a faster recovery in regions, cities and rural areas after the pandemic. This approach can be particularly effective in smaller countries such as the Czech Republic and Poland with a small number of inhabitants to price new tourism strategies economically. Therefore, the Euroregions supports financially the cross-border destinations of Germany, the V 4 countries Czech Republic, Poland as well as Austria. This article concludes that collaborative destination management should above all support the development of cross-border products. This can be implemented by offering virtual and digital tourism services (e. g. towns and cities, architecture, UNESCO World Heritage sites etc.). In addition, the elaboration of common hygiene concepts and coordination of requirements for tourists is unavoidable, as tourists should feel safe and comfortable during their stay. Lastly sustainable tourism should always be considered in the tourism marketing of the destinations. The development of visitor guidance measures offers the possibility to equalise tourist flows, and also the offer of interactive maps is a good orientation and encourages the visitors to stay on the paths and thereby protect nature.

Given the current restrictions and obstacles, especially in the tourism sector, the future of the Euroregions' cross-border collaboration is unpredictable. Nevertheless, these recommendations of action are designed both to maintain the inter-destination collaboration during crises and to establish new, innovative tourism approaches. Hopefully, the cooperation in 
these regions which is exemplary for other border regions in the European Union, can be continued successfully.

\section{References}

Abrhám, J. 2017. Project management and funding in the euroregions. In Polish Journal of Management Studies, vol. 16, 2017, no. 1, pp. 7-20. doi:10.17512/pjms.2017.16.1.01

Auswärtiges Amt. 2021. Grenzüberschreitende Zusammenarbeit in den Euroregionen. https://prag.diplo.de/cz-de/themen/politik/seite-zusammenarbeit-euroregionen/1 124524?openAccordionld=item-1217666-3-panel

Bramwell, B. - Lane, B. 2000. Tourism, collaboration, and partnership: Politics, practice, and sustainability. Aspects of tourism: vol. 2. Channel View Publications. http://site.ebrary.com/lib/uniregensburg/Doc?id $=10603458$

Dandage, R. - Mantha, S. - Rane, S. 2019. Strategy development using TOWS matrix for international project risk management based on prioritization of risk categories. In International Journal of Managing Projects in Business, vol. 12, 2019, no. 4, pp. 1003-1029. doi: 10.1108/JMMB-07-2018-0128

European Week of Regions and Cities. 2020. Cross-Border Cooperation \& Covid 19. https://europa.eu/regions-and-cities/programme/sessions/1234 en

Euroregion. 2014. Strategische Handlungsempfehlungen der Euroregion Neisse-Nisa-Nysa 2014-2020. https://www.euroregion-neisse.de/fileadmin/documents/euroregion/ de-strategische-handlungsempfehlungen-2014-2020.pdf

Iguman, S. 2020. If visitors won't go to Heritage, Heritage must go to visitor. Digitisation of Heritage in time of Corona. In Tourism facing a pandemic: From crisis to recovery. 2020, pp. 165-172.

INTERREG. 2020. About Interreg. What is Interreg and how it works. Interreg.eu. https://interreg.eu/about-interreg/

Naipaul, S. - Wang, Y. - Okumus, F. 2009. Regional destination marketing: a collaborative approach. In Journal of Travel \& Tourism Marketing, vol. 26, 2009, no. 5-6, pp. 462481. doi:10.1080/10548400903162998

Niestadt, M. 2020. EU tourism sector during the coronavirus crisis. EPRS European Parliamentary Research Service. https://www.europarl.europa.eu/RegData/etudes/ BRIE/2020/652008/EPRS BRI(2020)652008 EN.pdf
OECD. 2020. Tourism Policy Responses to the coronavirus (Covid-19). https://www.oecd. org/coronavirus/policy-responses/tourism-policy-responses-to-the-coronaviruscovid-19-6466aa20/

"Eine europäische Destination": Sächsische und Böhmische Schweiz sollen touristisch weiter zusammenwachsen. Landkreis Sächsische Schweiz - Osterzgebirge. 2021, April 30. https://www.landratsamt-pirna.de/eine-europaeische-destination-saechsischeund-boehmische-schweiz-sollen-touristisch-weiter-zusammenwachsen-10818. $\underline{\mathrm{html}}$

Peyrony, J. 2020. The effects of Covid-19 induced border closrues on cross-border regions. https://cor.europa.eu/en/engage/studies/Documents/The\%20effects\%200f\%20 Covid-19\%20induced\%20border\%20closures\%20on\%20cross-border\%20regions/ Covid-19\%20induced\%20border.pdf

Ravanavar, G. - Charantimath, P. 2012. Strategic Formulation Using Tows Matrix - A Case Study. In International Journal of Research and Development, vol. 1, 2012, no. 1, pp. 87-90.

Visegrad Group. 2020. Polish Presidency of the Visegrad Group July 2020-June 2021: Presidency Programm. https://www.visegradgroup.eu/download.php?doclD=451

Weihrich, H. 1982. The TOWS matrix - A tool for situational analysis. In Long Range Planning, vol. 15, 1982, no. 2, pp. 54-66. https://doi.org/10.1016/0024-6301(82)90120-0

\section{Contact address}

Gabriela Antošová, Czech Technical University, Masaryk Institute of Advanced Studies, Czech Republic, e-mail: gabriela.antosova@cvut.cz ORCiD https://orcid.org/0000-0001-5330-679X 